\title{
The influence of fertilization and tillage method on the formation root system capacity and grain production of spring barley
}

\author{
Andrej Kupecsek-Juliana Molnárová \\ Department of Crop Production, Faculty of Agrobiology and Food Recourses, \\ Slovak University of Agriculture in Nitra, Tr. A. Hlinku 2, 94976 Nitra, Slovakia \\ andrej.kupecsek@gmail.com
}

Keywords: spring barley, root system capacity, grain yield

SUMMARY

To evaluate the interaction of year $x$ variety, year $x$ tillage method and year $x$ fertilization on the grain yield and root system capacity (RSC) of spring barley, we ran polyfactorial field trials in agroecological conditions of a warm corn production area in Slovakia, at Malanta, in 2009 and 2010. The RSC measurements were done using LCR - meter at a frequency of $1 \mathrm{kHz}$ and they took place in four growth stages: at leaf development in the stage of four leaves (RSC1), in full tillering (RSC2), in the stage heading (RSC 3) and at the stage of ripening (RSC4). The values of grain yield, RSC1, RSC2, RSC3, RSC4 reached in 2009 comparison to 2010 were significantly lower. The highest yield in 2009 was reached by variety Marthe (4.49 t.ha $\left.{ }^{-1}\right)$ and by variety Bojos ( $\left.7.19 t \mathrm{ta}^{-1}\right)$ in 2010. The highest values of RSC in observed growth stages were achieved by variety Bojos in 2009, and in 2010 also besides RSC1. Within both years, difference in yields between tillage methods was not observed. The values of RSC in growth stage of 4 leaves and tillering was higher at conventional tillage, but the values of RSC3 and RSC4 were higher with minimized tillage. The highest grain yield and values of RSC in every growth stage were achieved on the fertilization variant " $c$ " in 2009 and on the fertilization variant " $b$ " in 2010. The correlation relationships between grain yield and RSC were significant and positive in every growth stage. The strongest relationship was found among grain yield and RSC $(r=0.6047)$.

\section{INTRODUCTION}

Time and expanse are major constraints limiting the detection of genotypic differences in the length, structure and growth rate of a root system. A conceptual model is presented that provides a rational basis for using plant root capacitance as an in-situ measurement for assessing plant root development. Capacitance maters may facilitate the non-destructive identification of genotypes with root characteristics that confer adaptation to various environments (van Beem, Smith and Zobel, 1998; Dalton, 1995). The electrical capacitance method is based on the polarization of biological membranes in the root system, and is dependent on the geometric and dielectric properties of the root system. The electrical capacitance or LCR meter measures the amount of electric charge stored by the root system for a given electric potential (in farads), which is dependent on the active root surface area and root length (McBride, Candido and Ferguson, 2007). According to Chloupek et al. (2010), a significant correlation between the electric capacity of the root system and its weight, volume and root surface can be found. Their results indicated that higher yields of barley were correlated with a greater root system size in dry environments. Lampurlanés, Angás and Cantero-Martínez (2001) state that surface conditions are of major importance to water infiltration into soil and determine the differences observed between tillage systems in deep soils. No-tillage is potentially better for semiarid regions because it maintains greater water content in the soil and promotes root growth in the surface soil. This is even the case deep in the soil profile, especially in years of low rainfall. The results of Zhang et al. (2009) indicate that total root length is not a factor that determines soil water use; rather, the distribution of root length density along the soil profile plays a more important role in soil water utilization. Smaller root size in the upper soil layer did not affect soil water uptake, and might be more economical in terms of production efficiency.

The aim of the study was to evaluate the interaction of year $\mathrm{x}$ variety, year $\mathrm{x}$ tillage method and year $\mathrm{x}$ fertilization on the grain yield and root system capacity (RSC) of spring barley.

\section{MATERIAL AND METHOD}

The research was completed within polyfactorial field trials in agroecological conditions of a warm corn production area in Slovakia, at Malanta, in 2009 and 2010. The trials were established by split plot method in three repetitions. According to the 50 years climate normal, the average annual rainfall is $532.5 \mathrm{~mm}$, the average annual air temperature is $9.8^{\circ} \mathrm{C}$ (Špánik, Repa and Šiška, 2002). According to Tobiášová and Šimanský (2009) the soil is loamy with low and medium humus content (1.99-2.19\%), pH 5.72, porosity at a depth of 0.00 to 0.30 $\mathrm{m}$ is low (37.0-40.7\%). We studied four spring barley varieties: Bojos, Kangoo, Marthe, Xanadu; two tillage methods: conventional tillage (ploughing to the depth of $0.18 \mathrm{~m}$ ) and minimize tillage (disk harrowing to the depth of 0.10 to $0.12 \mathrm{~m}$ ). Also we studied four variants of fertilization. The first was unfertilized; the second was fertilized with an organic fertilizer Condit mineral at a dose of $1 \mathrm{t} \mathrm{ha}^{-1}$ before sowing. On the third variant we applied $60 \mathrm{~kg} \mathrm{~N}$ as saltpeter nitrate with limestone (SNL) + leaf fertilizer (Hakofyt extra), and on the fourth 60 $\mathrm{kg} \mathrm{N}$ as $\mathrm{NH}_{4} \mathrm{NO}_{3}+$ leaf fertilizer (Hakofyt extra). Foliar fertilizer Hakofyt extra we applied on the base of leaf 
analysis. Soil samples were taken to determine the $\mathrm{N}_{\text {in }}, \mathrm{P}$ and $\mathrm{K}$ content before fertilization. Doses of $\mathrm{P}$ and $\mathrm{K}$ of fertilizers were calculated according to substitution system for yield level of $7.0 \mathrm{t} \mathrm{ha}^{-1}$. The root system capacity (RSC) measurements were done using LCR - meter type ELC - 133A at a frequency of $1 \mathrm{kHz}$. To RSC measurement we used clamp electrode (Rajkai, Végh and Nacsa, 2005). Measurements have taken place in four growth stages: at leaf development in the stage of four leaves (BBCH 13-15 - RSC1), in full tillering (BBCH 2325 - RSC2), in the stage heading (BBCH 51 - RSC 3) and at the stage of ripening (BBCH 85-89 - RSC4). Achievements were statistically evaluated by analysis of variance (ANOVA) in the program package Statistica 8 , and the means were tested with Tukey HSD test. In this paper, we will evaluate the interactions year $\mathrm{x}$ variety, year $\mathrm{x}$ tillage method, year $\mathrm{x}$ fertilization. The relationship among grain yield and RSC at each growth stage was expressed by correlation coefficient (r) (Table 1).

Table 1

Meteorological data of Dolná Malanta

\begin{tabular}{|c|c|c|c|c|c|c|}
\hline \multirow{2}{*}{ Months } & \multicolumn{3}{|c|}{$\begin{array}{c}\text { Average monthly } \\
\text { temperature }\left(\mathrm{T}^{\circ} \mathrm{C}\right)\end{array}$} & \multicolumn{3}{c|}{$\begin{array}{c}\text { Total monthly } \\
\text { rainfall (mm) }\end{array}$} \\
\cline { 2 - 7 } & $\begin{array}{c}\text { Average } \\
1960-1990\end{array}$ & 2009 & 2010 & $\begin{array}{c}\text { Average } \\
1960-1990\end{array}$ & 2009 & 2010 \\
\hline January & $-1,7$ & $-1,3$ & $-2,89$ & 31,0 & 41,7 & 0 \\
\hline February & 0,7 & 1,2 & 0,23 & 32,0 & 57,3 & 0 \\
\hline March & 5,0 & 5,5 & 5,30 & 30,0 & 53,6 & 20,10 \\
\hline April & 10,4 & 14,0 & 10,60 & 39,0 & 10,1 & 95,30 \\
\hline May & 15,1 & 15,5 & 15,16 & 58,0 & 38,1 & 156,30 \\
\hline Jun & 18,0 & 17,1 & 20,14 & 66,0 & 79,4 & 158,30 \\
\hline July & 19,8 & 20,6 & 23,01 & 52,0 & 69,8 & 51,90 \\
\hline August & 19,3 & 21,0 & 19,51 & 61,0 & 49,8 & 103,30 \\
\hline
\end{tabular}

\section{RESULTS AND DISCUSSION}

Analysis of variance (Table 2) showed a significant effect of year on all characteristics examined. Effect of variety was significant on the grain yield and RSC2 and RSC3. Tillage method and fertilization have had significant effect on RSC2 and RSC4 and in addition, fertilization had a significant on the grain yield. The interaction year x variety had significant effect on grain yield, RSC1, RSC3, year x tillage method on RSC2, year x fertilization on grain yield, and RSC1 and RSC4.

The values of grain yield, RSC1, RSC2, RSC3, RSC4 reached in 2009 comparison to 2010 were significantly lower. The highest yield in 2009 was reached by variety Marthe (4.49 t.ha ${ }^{-1}$ ). Viewed varieties in 2009 did not reach significant differences in grain yield. Significantly higher grain yield was achieved by variety Bojos (7.19 t $\mathrm{ha}^{-1}$ ) in 2010. The grain yield achieved by varieties Xanadu and Kangoo was lower by 1.02 and $1.95 \mathrm{t}^{-h} \mathrm{a}^{-1}$ respectively. The values of RSC1 ranged from $0.519 \mathrm{nF}$ (Kangoo) to $0.637 \mathrm{nF}$ (Bojos) in 2009. There was no significant difference found between varieties in RSC1 in 2009. The values of RSC1 were significantly greater for each variety in 2010. The highest values of RSC1 were achieved by variety Kangoo (1.148 nF). There was no significant difference found between the varieties for values of RSC1 in 2010. The values of RSC 2 ranged from $0.867 \mathrm{nF}$ (Kangoo) to $1.072 \mathrm{nF}$ (Bojos) in 2009 and there was no significant difference found between the varieties for values of RSC2 in 2009. The highest values of RSC2 were reached by variety Bojos (1.844 $\mathrm{nF})$ compared to variety Kangoo $(1.148 \mathrm{nF})$ in 2010. Variety Xanadu (1.783 nF) also reached significantly higher values of RSC2 compared to Kangoo. The variety Bojos $(0.409 \mathrm{nF})$ was the best variety for values of RSC3 in 2009. For RSC3 significant differences were found between Bojos $(0.790 \mathrm{nF})$ and Kangoo $(0.564 \mathrm{nF})$. In terms of RSC4, years 2009 and 2010 were very similar. Significant differences were observed between varieties Marthe (0.162 nF from 2009) and Bojos (0.244 nF from 2010) and Marthe (0.227 nF from 2010) (Table 3). 
Analysis of variance on grain yield and root system capacity in growth stages BBCH 13-15 (RSC1), BBCH 23-25 (RSC2), BBCH 51 (RSC3), BBCH 85-89 (RSC4)

\begin{tabular}{|c|c|c|c|c|c|c|}
\hline & Df & Grain yield & RSC1 & RSC2 & RSC3 & RSC4 \\
\hline Year (A) & 1 & 0.000000 & 0.000000 & 0.000000 & 0.000000 & 0.000104 \\
\hline Variety (B) & 3 & 0.000110 & NS & 0.000001 & 0.000301 & NS \\
\hline Tillage method (C) & 1 & NS & NS & 0.000000 & NS & 0.034239 \\
\hline Fertilization (D) & 3 & 0.000004 & NS & 0.000004 & NS & 0.031616 \\
\hline $\mathrm{A} \times \mathrm{B}$ & 3 & 0.000035 & 0.031010 & NS & 0.020599 & NS \\
\hline $\mathrm{A} \times \mathrm{C}$ & 1 & NS & NS & 0.000517 & NS & NS \\
\hline $\mathrm{B} \times \mathrm{C}$ & 3 & NS & NS & 0.001252 & NS & NS \\
\hline $\mathrm{A} \times \mathrm{D}$ & 3 & 0.000000 & 0.007684 & NS & NS & 0.011823 \\
\hline $\mathrm{B} \times \mathrm{D}$ & 9 & NS & 0.041037 & NS & NS & NS \\
\hline $\mathrm{C} \times \mathrm{D}$ & 3 & NS & NS & NS & NS & NS \\
\hline Error & 161 & & & & & \\
\hline Total & 191 & & & & & \\
\hline
\end{tabular}

Df-degree of freedom, NS-not significant

Influence of year and variety in grain yield and root system capacity in growth stages BBCH 13-15 (RSC1), BBCH 23-25 (RSC2), BBCH 51 (RSC3), BBCH 85-89 (RSC4)

\begin{tabular}{c|c|c|c|c|c|c} 
Year & Variety & $\begin{array}{c}\text { Yield } \\
\left(\mathrm{t} . \mathrm{ha}^{-1}\right)\end{array}$ & $\begin{array}{c}\text { RSC1 } \\
(\mathrm{nF})\end{array}$ & $\begin{array}{c}\text { RSC2 } \\
(\mathrm{nF})\end{array}$ & $\begin{array}{c}\text { RSC3 } \\
(\mathrm{nF})\end{array}$ & $\begin{array}{c}\text { RSC4 } \\
(\mathrm{nF})\end{array}$ \\
\hline \multirow{3}{*}{2009} & Xanadu & $4.13 \mathrm{a}$ & $0.525 \mathrm{a}$ & $1.037 \mathrm{a}$ & $0.377 \mathrm{a}$ & $0.180 \mathrm{ab}$ \\
& Bojos & $4.18 \mathrm{a}$ & $0.637 \mathrm{a}$ & $1.072 \mathrm{a}$ & $0.409 \mathrm{a}$ & $0.206 \mathrm{ab}$ \\
& Marthe & $4.49 \mathrm{ab}$ & $0.585 \mathrm{a}$ & $0.963 \mathrm{a}$ & $0.315 \mathrm{a}$ & $0.162 \mathrm{~b}$ \\
& Kangoo & $4.35 \mathrm{ab}$ & $0.519 \mathrm{a}$ & $0.867 \mathrm{a}$ & $0.375 \mathrm{a}$ & $0.179 \mathrm{ab}$ \\
\hline \multirow{2}{*}{2010} & Xanadu & $6.17 \mathrm{c}$ & $0.985 \mathrm{~b}$ & $1.783 \mathrm{~b}$ & $0.680 \mathrm{bc}$ & $0.218 \mathrm{ab}$ \\
& Bojos & $7.19 \mathrm{~d}$ & $0.951 \mathrm{~b}$ & $1.844 \mathrm{~b}$ & $0.790 \mathrm{c}$ & $0.224 \mathrm{a}$ \\
& Marthe & $6.71 \mathrm{~cd}$ & $1.026 \mathrm{~b}$ & $1.657 \mathrm{bc}$ & $0.657 \mathrm{cb}$ & $0.227 \mathrm{a}$ \\
& Kangoo & $5.24 \mathrm{~b}$ & $1.148 \mathrm{~b}$ & $1.492 \mathrm{c}$ & $0.564 \mathrm{~b}$ & $0.208 \mathrm{ab}$
\end{tabular}

Mean values followed by the same letter within columns are not significantly different $(p<0.05)$ according to the Tukey test.

There were significant differences found between years for the observed tillage methods in grain yields. But, within both years, the difference in yields between tillage methods was not observed. Higher yield was achieved

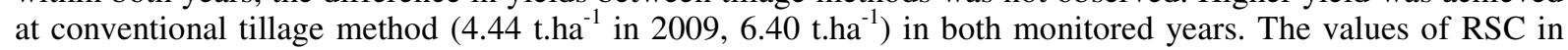
growth stage of 4 leaves and tillering was higher at conventional tillage $(0.576 \mathrm{nF}$ and $1.167 \mathrm{nF}$ in $2009,1.055$ and $2.008 \mathrm{nF}$ in 2010, respectively). This trend was change to growth stages of heading and maturing. The values of RSC3 and RSC4 were higher at the minimized tillage, $0.383 \mathrm{nF}$ and $0.185 \mathrm{nF}$ in 2009 , and $0.678 \mathrm{nF}$ $0.236 \mathrm{nF}$ in 2010 (Table 4).

Interaction of year and fertilization has had a statistically significant effect on the grain yield. In the drier year 2009 the yields were significantly lower compared to year 2010. The lowest grain yield was achieved on the

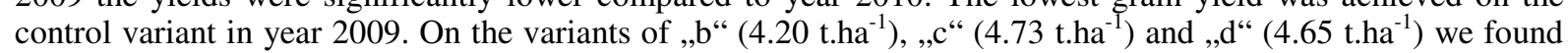
a significantly higher grain yield compared to the control variant. The highest grain yield was achieved on the variant ,b“ (7.60 t.ha $\left.{ }^{-1}\right)$, on which we applied organo-mineral fertilizer Condit. In case of industrial fertilizers the combination with leaf fertilizer Hakofyt extra, as an optional combination occurred to be the combination of SNL + Hakofyt (variant ,"c“), at which the highest grain yield was achieved in year 20094.73 t.ha $^{-1}$. The grain yield on ,"c" variant reached $6.15 \mathrm{t}^{\text {.ha }}{ }^{-1}$ in year 2010. The effect of grain yield was conditioned by year. The fertilization had no significant reflection in 2009. The values of RSC1 ranged form $0.507 \mathrm{nF}$ (variant ,a“) to $0.611 \mathrm{nF}$ (variant ,"c“). Significant differences were recorded for values of RSC1 affected by year on every fertilization variant in favor of year 2010. Significant differences were found for RSC between varieties in year 2010. From the monitored fertilization variants as an optional occurred to be variant „, $b^{\text {“ }}$ on which the organomineral fertilizer Condit was applied with the highest values of RSC1 (1.178 nF), RSC3 (0.740 nF), RSC4 $(1.808 \mathrm{nF})$. The significantly highest values of RSC2 were recorded on variant „,“ (1.808 nF) (Table 5). MunozRomero (2010) states, that root system development and productivity were both greater under no tillage than conventional. It has been shown that a key factor in the development of a good wheat root system is the rainfall recorded during the tillering stage, regardless of both soil water content at planting and rainfall before or after of 
this growth stage. This fact could be of interest in connection with the nitrogen fertilizer response as a function of the rainfall-root system development at tillering.

Influence of year and tillage method in grain yield and root system capacity in growth stages BBCH 13-15 (RSC1), BBCH 23-25

\begin{tabular}{c|c|c|c|c|c|c}
\multicolumn{2}{c}{ (RSC2), BBCH 51 (RSC3), BBCH 85-89 (RSC4) } \\
Year & Tillage method & $\begin{array}{c}\text { Yield } \\
(\mathrm{t} / \mathrm{ha})\end{array}$ & $\begin{array}{c}\text { RSC1 } \\
(\mathrm{nF})\end{array}$ & $\begin{array}{c}\text { RSC2 } \\
(\mathrm{nF})\end{array}$ & $\begin{array}{c}\text { RSC3 } \\
(\mathrm{nF})\end{array}$ & $\begin{array}{c}\text { RSC4 } \\
(\mathrm{nF})\end{array}$ \\
\hline \multirow{2}{*}{2009} & Conventional & $4.44 \mathrm{a}$ & $0.576 \mathrm{a}$ & $1.167 \mathrm{a}$ & $0.354 \mathrm{a}$ & $0.178 \mathrm{a}$ \\
& Minimized & $4.14 \mathrm{a}$ & $0.557 \mathrm{a}$ & $0.802 \mathrm{~b}$ & $0.383 \mathrm{a}$ & $0.185 \mathrm{a}$ \\
\hline \multirow{2}{*}{2010} & Conventional & $6.40 \mathrm{~b}$ & $1.055 \mathrm{~b}$ & $2.008 \mathrm{c}$ & $0.668 \mathrm{~b}$ & $0.203 \mathrm{ab}$ \\
& Minimized & $6.26 \mathrm{~b}$ & $1.000 \mathrm{~b}$ & $1.380 \mathrm{~d}$ & $0.678 \mathrm{~b}$ & $0.236 \mathrm{~b}$
\end{tabular}

Mean values followed by the same letter within columns are not significantly different $(p<0.05)$ according to the Tukey test.

Influence of year and fertilization in grain yield and root system capacity in growth stages BBCH 13-15 (RSC1), BBCH 23-25 (RSC2), BBCH 51 (RSC3), BBCH 85-89 (RSC4)

\begin{tabular}{l|l|c|c|c|c|c} 
Year & \multicolumn{1}{|c|}{ Fertilization } & $\begin{array}{c}\text { Yield } \\
(\mathrm{t} / \mathrm{ha})\end{array}$ & $\begin{array}{c}\mathrm{RSC} 1 \\
(\mathrm{nF})\end{array}$ & $\begin{array}{c}\mathrm{RSC} 2 \\
(\mathrm{nF})\end{array}$ & $\begin{array}{c}\mathrm{RSC} 3 \\
(\mathrm{nF})\end{array}$ & $\begin{array}{c}\text { RSC4 } \\
(\mathrm{nF})\end{array}$ \\
\hline \multirow{5}{*}{2009} & Control & $3.58 \mathrm{c}$ & $0.507 \mathrm{a}$ & $0.862 \mathrm{a}$ & $0.352 \mathrm{a}$ & $0.159 \mathrm{a}$ \\
& Condit & $4.20 \mathrm{ac}$ & $0.552 \mathrm{a}$ & $0.987 \mathrm{a}$ & $0.367 \mathrm{a}$ & $0.179 \mathrm{a}$ \\
& $\mathrm{SNL}+$ Hakofyt & $4.73 \mathrm{ad}$ & $0.611 \mathrm{a}$ & $1.051 \mathrm{a}$ & $0.401 \mathrm{a}$ & $0.191 \mathrm{a}$ \\
& $\mathrm{NH}_{4} \mathrm{NO}_{3}+$ Hakofyt & $4.65 \mathrm{a}$ & $0.596 \mathrm{a}$ & $1.040 \mathrm{a}$ & $0.356 \mathrm{a}$ & $0.197 \mathrm{a}$ \\
\hline \multirow{3}{*}{2010} & Control & $5.95 \mathrm{~b}$ & $1.037 \mathrm{bc}$ & $1.482 \mathrm{c}$ & $0.701 \mathrm{~b}$ & $0.205 \mathrm{a}$ \\
& Condit & $7.60 \mathrm{e}$ & $1.178 \mathrm{c}$ & $1.697 \mathrm{bc}$ & $0.740 \mathrm{~b}$ & $0.265 \mathrm{~b}$ \\
& $\mathrm{SNL}+$ Hakofyt & $6.15 \mathrm{~b}$ & $0.890 \mathrm{~b}$ & $1.808 \mathrm{~b}$ & $0.615 \mathrm{~b}$ & $0.211 \mathrm{ab}$ \\
& $\mathrm{NH}_{4} \mathrm{NO}_{3}+$ Hakofyt & $5.61 \mathrm{bd}$ & $1.005 \mathrm{bc}$ & $1.788 \mathrm{~b}$ & $0.635 \mathrm{~b}$ & $0,197 \mathrm{a}$
\end{tabular}

Correlation relationship among grain yield and root system capacity in growth stages BBCH 13-15 (RSC1), BBCH 23-25 (RSC2), BBCH 51 (RSC3), BBCH 85-89 (RSC4)

\begin{tabular}{|c|c|c|c|c|}
\hline & $\mathrm{RSC} 1$ & $\mathrm{RSC} 2$ & $\mathrm{RSC} 3$ & $\mathrm{RSC} 4$ \\
\hline Garin yield & $0,4801 * * *$ & $0,5291 * * *$ & $0,6047 * * *$ & $0,3540 * * *$ \\
\hline
\end{tabular}

The correlation relationships between grain yield and RSC were significant and positive in every growth stage. The strongest relationship was found among grain yield and RSC $(\mathrm{r}=0.6047)$ (Table 6). From above tables is an obvious increase of RSC observed till growth stage of tillering, after which a depression is showed from growth stage of heading. Even Chloupek (1977) states that depression is higher towards the end of vegetation. According to Pietola (2005), after grain formation the root numbers decreased toward full ripeness.

\section{CONCLUSION}

From the results of monitoring the effect of variety, fertilization and tillage method in interaction with year on the development of root system capacity and grain yield of spring barley and from the correlation relationships of grain yield and RSC the following conclusions are derived:

The values of grain yield, RSC1, RSC2, RSC3, RSC4 reached in 2009 in comparison to 2010 were significantly lower. The highest yield in 2009 was reached by variety Marthe (4.49 t.ha ${ }^{-1}$ ) and by variety Bojos $\left(7.19 \mathrm{t} \mathrm{ha}^{-1}\right)$ in 2010. The highest values of RSC in observed growth stages were achieved by variety Bojos in 2009, and in 2010 laso besides RSC1. Within both years the difference in yields between tillage methods was not observed. The values of RSC in growth stage of 4 leaves and tillering was higher at conventional tillage, but the values of RSC3 and RSC4 were higher at the minimized tillage. The highest grain yield and values of RSC in every growth stage was achieved on the fertilization variant ,c" in 2009 and on the fertilization variant „b“ in 2010. The correlation relationships between grain yield and RSC were significant and positive in every growth stage. The strongest relationship was found among grain yield and RSC ( $\mathrm{r}=0.6047)$. 


\section{ACKNOWLEDGEMENTS}

The paper was supported by VEGA project 1/0551/08 a 1/0237/11.

\section{REFERENCES}

Been van, J.-Smith, M.E.-Zobel, R.W. (1998): Estimating root mass in maize using portable capacitance mater. Agronomy Journal, 94 (4), 566 - 570.

Chloupek, O. (1977): Evaluation of the size of a plant's root system using its electrical capacitance. Plant and Soil 48, 525-532.

Chloupek O.-Dostál V.-Středa T.-Psota V.-Dvořáčková O. (2010): Drought tolerance of barley varieties in relation to their root system size. Plant Breeding. 129, 630-636.

Dalton, F.N.: 1995. In-situ root extent measurement by electrical capacitance methods. Plant and soil, 173, 157 165.

Lampurlanés J.-Angás P.-Cantero-Martínez C. (2001): Root growth, soil water content and yield of barley under different tillage systems on two soils in semiarid conditions. Field Crops Research. 69, 27-40.

McBride, R-Candido, M.-Ferguson J. (2008): Estimating root mass in maize genotypes using the electrical capacitance method. Agronomy and Soil Science, 54, 215 - 226.

Munoz-Romero V.-Benítez-Vega J.-López-Bellido L.-López-Bellido R.J. (2010): Monitoring wheat root development in a rainfed vertisol: Tillage effect. European Journal of Agronomy. 33 (3), 182-187.

Pietola, L.M. (2005): Root growth dynamics of spring cereals with discontinuation of moldboard ploughing. Soil \& Tillage Research, 80, $103-114$.

Rajkai, K.-Végh, K. R.-Nacsa, T. (2005): Electrical capacitance of root in relation to plant electrodes, measuring frequency and root media. Acta Agronomica Hungarica, 53, $197-210$.

Špánik F.-Repa Šs.-Šiška B. (2002): Agroklimatické a fenologické pomery Nitry : 1991-2000. Nitra : SPU, 39 p.

Tobiášová, E.-Šimanský, V. (2009): Kvantifikácia pôdnych vlastností a ich vzájomných vzt'ahov ovplyvnených antropickou činnost'ou. 1 vyd. Nitra:SPU, 114 p.

Zhang X.-Chen S.-Sun H. Wang Y.-Shao L. (2009): Root size, distribution and soil water depletion as affected by cultivars and environmental factors. Field crop research. 114, 75-83. 